\title{
Guardians of the Gut: Pretransplant IgA levels and seromucous infections
}

\author{
Jules Lin, MD
}

\footnotetext{
From the Section of Thoracic Surgery, Department of Surgery, University of Michigan Medical Center, Ann Arbor, Mich.

Disclosures: Author has nothing to disclose with regard to commercial support.

Received for publication March 25, 2018; accepted for publication March 29, 2018; available ahead of print May $10,2018$.

Address for reprints: Jules Lin, MD, Section of Thoracic Surgery, University of Michigan Medical Center, $1500 \mathrm{E}$ Medical Center Dr, 2120TC/5344, Ann Arbor, MI 48109-5344 (E-mail: juleslin@umich.edu).

J Thorac Cardiovasc Surg 2018;156:880-1

$0022-5223 / \$ 36.00$

Copyright (c) 2018 by The American Association for Thoracic Surgery

https://doi.org/10.1016/j.jtcvs.2018.03.129
}

In this issue of the Journal, Murthy and colleagues ${ }^{1}$ report that low pretransplant IgA levels predispose lung transplant recipients to seromucous infections and discriminate patients who may benefit from surveillance and prophylaxis. These findings have the potential to affect the course of a substantial number of patients after transplant, and infection continues to be a significant cause of morbidity and mortality. There are, however, some limitations to the study of Murthy and colleagues.

As with many transplant studies, timing is unpredictable, and the interval between when IgA levels were drawn and when transplant occurred was variable. It was as long as 3.5 years before transplant, and it was longer than 6 months in almost $50 \%$ of the cases. There is concern whether pretransplant levels remain stable and reflect IgA levels at the time of transplant. IgA levels can vary as a result of medications, including mycophenolate mofetil and cyclosporine (INN ciclosporin), and even seasonal changes have been noted. ${ }^{2}$

Donor and recipient posttransplant factors, which could affect the incidence of infection, were not included in the multivariable analysis. Such factors include induction therapy, blood transfusions, diabetes, cytomegalovirus prophylaxis, donor and recipient cultures, and leukopenia, and it is difficult to determine whether $\operatorname{IgA}$ levels are independent of these factors. A subset of patients was enrolled in 2 clinical trials that could affect infection outcomes. One randomized 136 patients to 3 versus 12 months of valganciclovir. The other evaluated hyperimmune globulin in cytomegalovirus-positive donor and cytomegalovirusnegative recipient transplant situations. Although hypogammaglobulinemia has been associated with increased infections, ${ }^{3}$ IgG levels were not associated with increased infections in the study of Murthy and colleagues, ${ }^{1}$ which may be because 25 patients with low IgG levels had their records censored after they received cytomegalovirus intravenous immune globulin.

Lung mucosal $\operatorname{IgA}$ is derived from local plasma cells, whereas circulating $\operatorname{IgA}$ is derived from bone marrow.

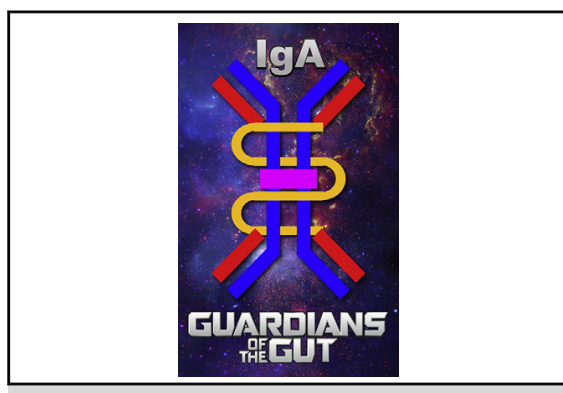

IgA, the Guardians of the Gut, protecting against seromucous infections. (Modified from NASA McortNGHH, and Marvel Comics [Public domain] via Wikimedia Commons.)

\section{Central Message}

Pretransplant IgA levels were associated with seromucous infections, but further studies are required to determine which patients need prophylaxis while incorporating donor and recipient risk factors.

See Article page 882 .
Bastian and associates ${ }^{4}$ found that bronchial-associated lymphoid tissue continues to produce IgA after lung transplantation. ${ }^{3}$ What is the relationship between circulating levels reported here and secretory IgA from local plasma cells? In addition, lower IgG and IgA levels have been associated with an increase in bronchiolitis obliterans syndrome. Is decreased survival associated with lower pretransplant $\operatorname{IgA}$ a result of bronchiolitis obliterans syndrome in addition to infections? Should IgA levels be checked in all patients, or just a subset? Previous studies have reported lower levels in patients with emphysema, increasing age, and male sex. ${ }^{6}$ Klooster and coworkers ${ }^{7}$ reported higher levels with idiopathic pulmonary fibrosis. How should IgA levels be monitored, and what is the relationship to other immunodeficiencies, such as hypogammaglobulinemia and hypocomplementemia ${ }^{8}$ ?

Although there are limitations to the study of Murthy and colleagues, ${ }^{1}$ the results are potentially important for a substantial number of transplant recipients, because infection continues to be a significant cause of morbidity and mortality. Further prospective studies are needed to determine how pretransplant IgA levels change with time and which patients need prophylaxis while incorporating donor and posttransplant recipient risk factors. IgA molecules, like the 
Guardians of the Galaxy, are not typical superheroes, and their role in immune function is often overlooked. Murthy and colleagues ${ }^{1}$ have reminded readers of their important role in lung transplant recipients as Guardians of the Gut, defending against infections of the mucous membranes.

\section{References}

1. Murthy SC, Avery RK, Budev M, Gupta S, Pettersson GB, Nowicki ER, et al. Low pre-transplant IgA level is associated with early post-lung transplant seromucous infection. J Thorac Cardiovasc Surg. 2018;156:882-91.e8.

2. Weber-Mzell D, Kotanko P, Hauer AC, Goriup U, Haas J, Lanner N, et al. Gender, age and seasonal effects on IgA deficiency: a study of 7293 Caucasians. Eur J Clin Invest. 2004;34:224-8.

3. Goldfarb NS, Avery RK, Goormastic M, Mehta AC, Schilz R, Smedira N, et al. Hypogammaglobulinemia in lung transplant recipients. Transplantation. 2001; $71: 242-6$.
4. Bastian A, Tunkel C, Lins M, Böttcher H, Hirt SW, Cremer J, et al. Immunoglobulin A and secretory immunoglobulin A in the bronchoalveolar lavage from patients after lung transplantation. Clin Transplant. 2000;14: $580-5$.

5. Yip NH, Lederer DJ, Kawut SM, Wilt JS, D’ Ovidio F, Wang Y, et al. Immunoglobulin $\mathrm{G}$ levels before and after lung transplantation. Am J Respir Crit Care Med. 2006;173:917-21.

6. Chambers DC, Davies B, Mathews A, Yerkovich ST, Hopkins PM. Bronchiolitis obliterans syndrome, hypogammaglobulinemia, and infectious complications of lung transplantation. J Heart Lung Transplant. 2013;32:36-43.

7. Ten Klooster L, van Moorsel CH, Kwakkel-van Erp JM, van Velzen-Blad H, Grutters JC. Immunoglobulin A in serum: an old acquaintance as a new prognostic biomarker in idiopathic pulmonary fibrosis. Clin Exp Immunol. 2015; 181:357-61.

8. Carbone J, Micheloud D, Salcedo M, Rincon D, Bañares R, Clemente G, et al. Humoral and cellular immune monitoring might be useful to identify liver transplant recipients at risk for development of infection. Transpl Infect Dis. 2008;10: 396-402. 